\title{
DOCUMENTARY SOURCES TO INVESTIGATE MULTIDECADAL VARIABILITY OF DROUGHTS
}

\author{
F. DOMÍNGUEZ-CASTRO ${ }^{1,2^{*}}$, R. GARCÍA-HERRERA ${ }^{3,4}$ \\ ${ }^{1}$ Departamento de Ingeniería Civil y Ambiental, Escuela Politécnica Nacional, Ecuador. \\ ${ }^{2}$ Instituto Nacional de Meteorología e Hidrología, Ecuador. \\ ${ }^{3}$ Dpto. Física de la Tierra II, Universidad Complutense de Madrid, Spain. \\ ${ }^{4}$ IGEO, Instituto de Geociencias (CSIC, UCM), Spain.
}

\begin{abstract}
Droughts are probably the natural hazard with the highest socioeconomic impact. Simultaneously, they are a very complex phenomenon; they are triggered by a diversity of physical factors and occur at a variety of time scales. Consequently, the instrumental record currently available is too short and the characterization of its multidecadal variability requires the use of natural proxies (tree rings, sedimentary records) or documentary sources. In this paper we analyse three documentary sources with potential to analyse the long-term variability of droughts: chapter acts, logbooks and chronicles. The chapter acts recorded discussions and decisions made during the assemblies of the local authorities and provide continuous and direct evidence on drought impacts. They are especially useful to study droughts between the $15^{\text {th }}$ and the $19^{\text {th }}$ centuries in Europe and the $17^{\text {th }}$ to $18^{\text {th }}$ in the former colonies. Logbooks recorded the meteorological conditions and the incidents occurred during navigation. They provide indirect information through the circulation indices that can be very helpful to understand the mechanisms and teleconnections associated to droughts. Finally, the chronicles are historiographical documents describing political and social events. They are secondary sources and the references to climatic events are discontinuous, thus their analysis must be extremely careful, but they are especially useful to study specific drought events especially prior to $15^{\text {th }}$ century when no other sources are available.
\end{abstract}

Fuentes documentales para investigar la variabilidad multidecadal de las sequías

RESUMEN. Las sequías son uno de los riesgos naturales que mayor impacto causan en la población y en la economía, por lo que estudiarlas es fundamental para poder implementar medidas de prevención y adaptación a las mismas. Sin embargo, son un fenómeno climático muy complejo que ocurre a distintas escalas temporales y se desencadena por una amplia variedad de factores físicos. El registro instrumental del que se dispone actualmente no es suficientemente largo 
para estudiar en detalle las sequías, especialmente su variabilidad multidecadal por lo que se hace necesario recurrir a otras fuentes de información como los proxies naturales (anillos de los árboles, registros sedimentarios...) o las fuentes documentales. En este trabajo analizamos tres fuentes documentales con potencial en el estudio de la variabilidad multidecadal de las sequías: actas capitulares, diarios de navegación y crónicas. Las actas capitulares registran las discusiones y decisiones tomadas por los gobiernos locales en sus reuniones. Destacan debido a que proporcionan información continua y directa sobre los impactos de las sequías y son de especial relevancia entre los siglos XV y XIX en Europa y en los siglos XVII y XVIII en las colonias. Los diarios de navegación son los registros que elaboran los navegantes durante sus rutas, en los que registran las condiciones meteorológicas de las mismas y los incidentes ocurridos. Presentan información indirecta de índices de circulación especialmente interesantes para entender los mecanismos y teleconexiones asociados a las sequías. Por último, las crónicas son documentos historiográficos que se realizan con el objetivo de describir eventos políticos y sociales. Sin embargo, se trata de fuentes documentales secundarias, donde las referencias a eventos climáticos son discontinuas. Por ello, deben ser tratadas con cautela. Las crónicas no son de gran utilidad para estudiar la variabilidad de las sequías, no obstante pueden ser muy útiles para estudiar eventos de sequía concretos, ya que en muchos casos son las únicas fuentes documentales que proporcionan información sobre sequías anteriores al siglo $X V$.

Key words: documentary sources, droughts, loogbooks, chapter acts, chronicles.

Palabras clave: fuentes documentales, sequías, diarios de navegación, actas capitulares, crónicas.

Received 16 January 2016

Accepted 2 March 2016

*Corresponding author: Departamento de Ingeniería Civil y Ambiental, Escuela Politécnica Nacional, Ecuador. E-mail: f.dominguez.castro@gmail.com

\section{Introduction}

Droughts are perhaps the natural hazards with the highest impact in terms of people affected and socioeconomic impact (Obasi, 1994). Additionally, they are among the more complex climatological/meteorological extreme events. This complexity has different origins. Even when drought can be defined as a period with precipitation deficit, this definition is difficult to apply for operational and research purposes. This has led to the identification of different types, such as meteorological, agricultural, hydrologic and socio-economic, depending on the natural or societal system involved (Wilhite and Glantz, 1985). Thus, the identification of the starting 
and ending of a drought is not a trivial task. Another source of complexity is the wide variety of physical factors triggering drought occurrence. They include synoptic atmospheric patterns such as blocking, the phase of the North Atlantic Oscillation or the location of the jetstream (Paredes et al., 2006; García-Herrera et al., 2007), which can explain the interannual variability. Remote and lagged teleconnections with oceanic patterns such as the Pacific Multidecadal Oscillation (PDO), El NiñoSouthern Oscillation (ENSO) or the Atlantic Multidecadal Oscillation (AMO) are also partly responsible of explaining variability in the decadal and multidecadal bands (Ionita et al., 2011). On top of this, the association between the forcing and the drought at a certain location is not necessarily stable in time (Vicente-Serrano and López-Moreno, 2008). As a consequence of the nonlinear interaction among these and other forcings, droughts occur at a variety of time scales, ranging from 2.5-5 years, 12-13 years to multidecadal (Sousa et al., 2011). Thus, a full characterization of droughts requires long and homogeneous series and the observational record is usually too short to cover the involved relevant time scales.

One of the few ways to overcome this problem is the use of climate proxies, i.e., variables correlated with climate parameters used to infer their past value. Thus, tree rings have been widely used as drought proxies in regions as the US (e.g. Stahle et al., 2007) and, recently, in Iberia (e.g. Esper et al., 2015; Tejedor et al., 2015). Lake sediments are also valuable drought proxies worldwide (e.g. Verschuren et al., 2000; Hodell et al., 2005; Domínguez-Castro et al., 2006; Martín-Puertas et al., 2008; Nelson et al., 2011).

Apart from these natural proxies, documents preserved in historical archives are also a relevant source to understand past climate variability. They can be either primary, those created at the time when the event occurred and from first-hand information, or secondary, which are those describing or discussing information contained previously in other sources. They have different origins from civil, church or military institutions to individuals and, in the last decades, have been widely used as climate proxies (Prieto and García-Herrera, 2009; Brádzil et al., 2010; Nash and Adamson, 2014). The aim of this paper is to review those documentary sources most frequently used to analyze long-term variability of droughts in different regions of the globe. We first review the primary sources with most direct information on droughts, i.e. chapter acts and rogations. Then we show the potential of logbooks, a primary source, as remote indicators of droughts. Later on we comment some results from chronicles, mostly secondary sources, which provide information on specific events. The paper ends with some final remarks.

\section{Documentary sources}

\subsection{Chapter acts}

Chapter acts (Actas Capitulares) were the documents produced by local governments since the Middle Ages. They recorded discussions and decisions made during the assemblies of the local authorities. They usually met weekly, but could increase the 
frequency if required, depending on the circumstances affecting the village. The system was later transferred to the Spanish colonies in America. According to Belmonte et al. (1987) they usually contained information on administrative policy, economy, urbanism, justice, demography, war, local taxes or public health. Due to the high frequency of the meetings, they can provide detailed first-hand information, especially during crisis, which were mostly associated to wars or natural hazards, the main threatens for these societies.

Documents produced by individuals usually cover short periods and/or have been lost or poorly preserved. However, this is not the case of the acts, since they reflect the life of institutions working for centuries. Thus, this source has two characteristics highly relevant to build climate proxies: continuity and homogeneity. They have been preserved in local or regional archives and its structure did not change substantially until the beginning of the $19^{\text {th }}$ century. The main climatological application of chapter acts is the analysis of extreme events, because they altered the cities life, reducing crops, damaging infrastructures or producing famines and epidemics. All these circumstances required prompt decisions from the chapter and were reflected in the acts. Rogation ceremonies are frequently recorded in chapter acts. These ceremonies are rituals of the Roman Catholic Church to beg for the end of divine punishment as a drought (pro-pluvia rogations) or a long wet/stormy spells (pro-serenitate rogations).

Pro-pluvia rogations are a good proxy of agricultural drought in preinstrumental period. This proxy is especially useful in catholic countries, with a good preservation of its historical documentation and with agriculture highly dependent of precipitation. These conditions are given in some southern European countries, mainly Spain and Italy. In Spain, the use of rogation ceremonies as a climatic proxy has been developed from the 1990s. Series of rogation ceremonies have been compiled in many cities around the country from about the $16^{\text {th }}$ to the $19^{\text {th }}$ centuries, i.e. Bilbao, Santo Domingo de la Calzada, Huesca, Barbastro, Calahorra, Girona, Vic, Barcelona, Cervera, Tarragona, Tortosa, Zaragoza, Teruel, Zamora, Toledo, Zafra, Sevilla and Murcia (Álvarez Vázquez, 1986; Sáez de Ocáriz, 1990; MartínVide and Barriendos, 1995; Barriendos, 1997; Zamora, 2002; Vicente-Serrano and Cuadrat, 2007; Domínguez-Castro et al., 2008; Rodrigo and Barriendos, 2008; Cuadrat, 2012; Fernández-Fernández et al., 2014). Also Domínguez-Castro et al., (2010, 2012a) used these series to study the drought spatial distribution in Iberia for the period 1600-1850. They showed that during the first half of the $17^{\text {th }}$ century droughts mostly had a local character, but from 1650 to 1750 droughts affected to broader regions or even to the whole Peninsula. The most extended droughts during the period 1600-1750 occurred at 1664 and 1680. The driest intervals for 1750-1850 were 1750-1754 and 1779-1783, and the most extended drought took place in 1817 influenced by the Tambora eruption (1815).

Rogations have also been analyzed in Italy, where Piervitali and Colacino (2001) retrieved the ceremonies celebrated at Erice (western Sicily) from 1565 to 1915 . However, in this case the information was extracted from a marble plate 
reporting the processions during the period, none from the council acts. This study points out the potential of rogation ceremonies to analyze droughts in Italy. For this reason Italy is an interesting country to extract rogation ceremonies series from chapter acts. Latin America has potential to use rogations as climate proxy, during the colonial period mainly the $17^{\text {th }}$ and $18^{\text {th }}$ centuries. The first works have been developed in central Mexico and rogations series are available from the city of México, Morelia, Guadalajara, Durango, Oaxaca, San Cristóbal de las Casas, Mérida and Puebla (Garza Merodio, 2007, 2014). In Ecuador, Terneus and Gioda (2006) compiled a preliminary work including the rogation ceremonies of Quito from an incomplete secondary source (de Dios Navas, 1926). Currently all the chapter acts of Quito, preserved in the Metropolitan Archive, have been compiled (Domínguez-Castro et al., 2015). Figure 1 shows a piece of a chapter acts from Quito from $5^{\text {th }}$ February of 1774 , including the request of a rogation ceremony: "atendiendo a la necesidad pública, por la extraordinaria sequedad y continuos soles que se experimentan, el que se trajese la Imagen de Nuestra Señora de Guadalupe." [attending to the public need, due to the unusual drought y continuous suns, bring the image of Our Lady of Guadalupe].

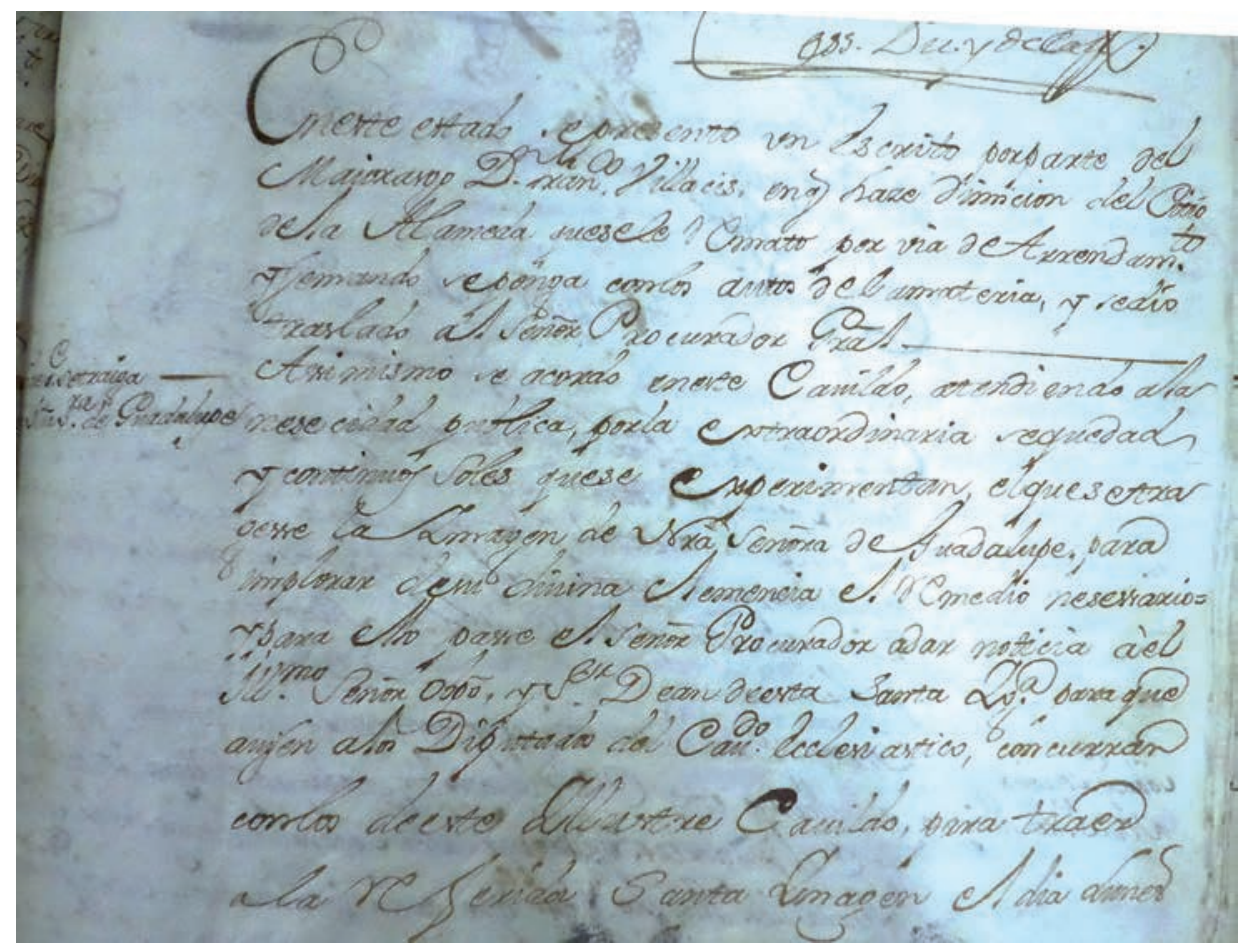

Figure 1. Chapter act from Quito from 5th February of 1774 preserved at the metropolitan archive of Quito. 
Rogation ceremonies are not the only interesting proxy information contained in chapter acts. García-Herrera et al. (2008) used chapter acts from Archivo Regional de La Libertad (Regional Archive of La Libertad), Trujillo (Northern Peru), jointly with other sources kept in the Archivo General de Indias (General Archive of Indies) in Seville and the Archivo General de la Nación (National General Archive) in Lima to produce a chronology of El Niño (EN) events for the period $1550-1900$. They were able to identify 59 EN years with the $17^{\text {th }}$ century appearing as the least active EN period, and 1620s, 1720s, 1810s, and 1870s the most active ones. Regarding droughts, Politis (1983) reconstructed the occurrence of droughts in Buenos Aires from 1589 to 1821 using acts and complementary information from maps and chronicles. Most of the relevant information included references to problems in agriculture and stockbreeder activity in the region. Politis (1983) was able to detect multidecaldal variability in the droughts frequency, with the 1698-1791 as the driest period in the record.

\subsection{Logbooks}

Due to different reasons, seamen kept record of relevant events along the route since the early times of transoceanic navigation. At the beginning of the sail era they had to identify safe routes to connect the respective mainland with the new territories and this was done by accumulating experience. Thus, in Spain, a Royal Order issued by Phillipe II in 1575 made mandatory for captains of the transatlantic route to write a dairy describing the route and incidences occurred along the trip. Upon return, the books were delivered to the Professor of Cosmology in Seville who used them twofold: to train captains and pilots and define the most appropriate course and timing for the different connections between Spain and the Indies. When explorations were completed and navigation developed on a routinely basis, logbooks were kept to testimony of every fact which could have an incidence in the daily life onboard, from diseases as scurvy, lack of supplies, problems with the cargo or encounters with enemies during war times. The ability to complete timely and safely a trip relied mostly on the crew expertise and their capacity to observe weather and sea and interpret them adequately. This made that meteorological observations were always recorded in the logbooks.

Figure 2 shows a page of the logbook of a Spanish mail ship sailing from La Coruña (NW Spain) to Havana in 1796. Interestingly, the layout is very similar to that used by the other contemporary sailing power such as England, France or the Netherlands. The first column shows the hour of observation, with the nautical day starting at noon, the second and third ones describe the wind direction and ships route according to the compass, the next one includes the wind force described in a semi quantitative scale similar to present day Beaufort wind scale. The next horizontal section includes all the computations made to estimate ship's position at noon and the bottom contains a narrative summary of the day (occurrence of precipitation, storms, relevant changes in the wind, problems in the ship managements...). 


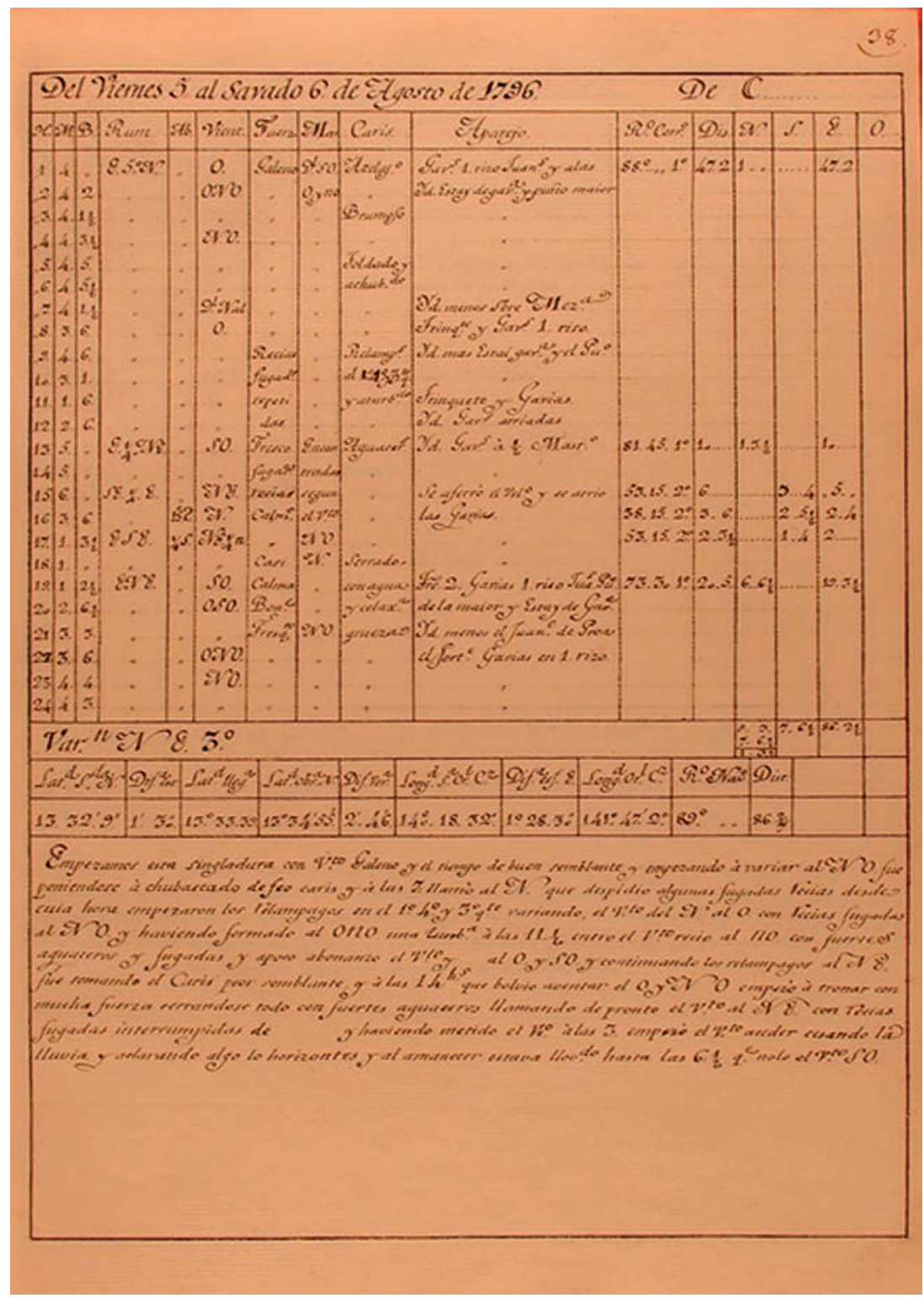

Figure 2. Logbook from a Spanish mail ship on its route from La Coruña to Havana corresponding to August 5-6, 1796. See text for details.

After 1853, when M. F. Maury organized the 'Brussels Maritime Conference', which defined the common standards for meteorological instrumental observations onboard, logbooks started to contain instrumental observations. Thus we have a very detailed source of high resolution (daily or even subdaily) meteorological 
information which embraces a region (the world's oceans) not covered by other sources. Figure 3 shows the spatial distribution of the retrieved data from logbooks by the Climatological Database for the World's Oceans 1750-1850 (CLIWOC) project (García-Herrera et al., 2005) and represents the most frequented oceanic routes for the period. The meteorological triggering of the routes is clear, with ships avoiding the center of the Azores High or having to sail far west in their trip to S Africa and India because of unfavorable wind conditions. Fortunately, thousands of logbooks have survived in different archives (Wheeler and GarcíaHerrera, 2008) containing a wealth of records mostly unexplored, with dozens of thousands logbooks still unabstracted.

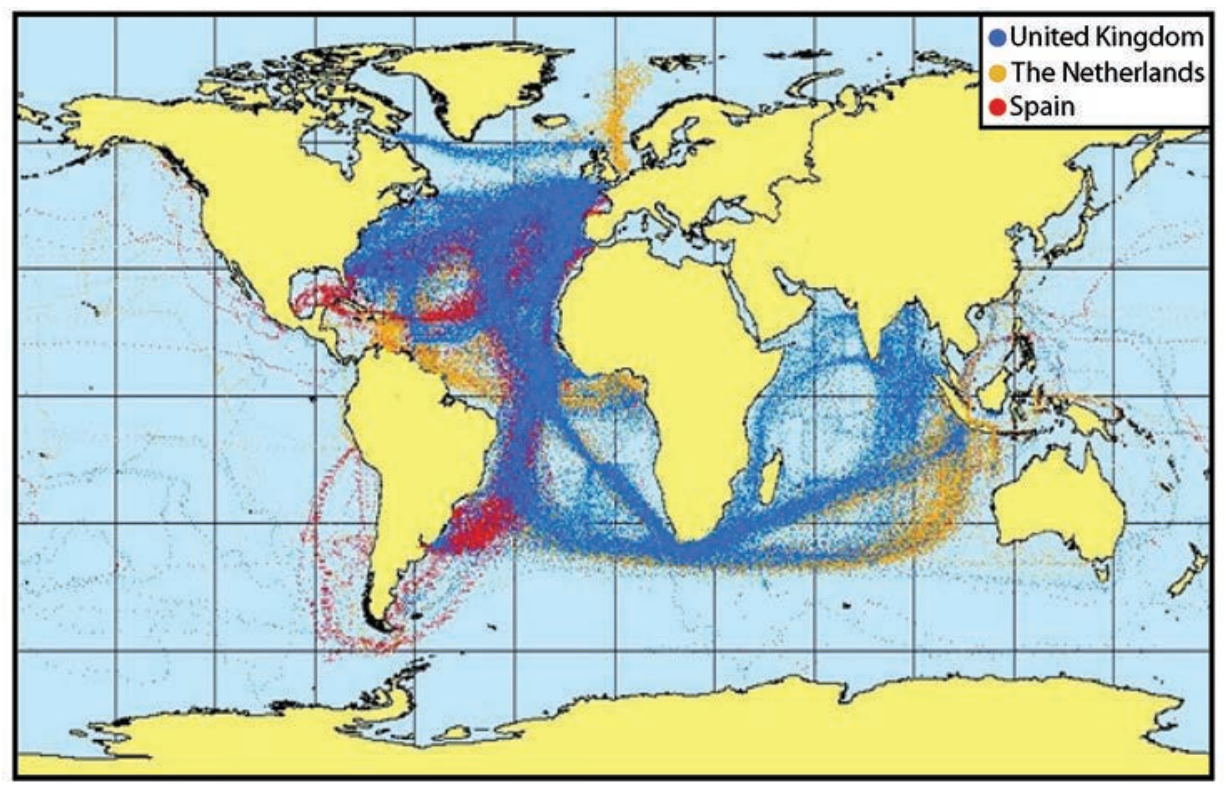

Figure 3. Wind observations recovered from logbooks from United Kingdom, The Netherlands and Spain in the Climatological Database for the World's Oceans 1750-1850 (CLIWOC) project. Each dot represents a midday observation. Modified from GarcíaHerrera et al. 2005.

The interest in using ship logbooks as a source of climatological information has been intermittent throughout time. Thus, in 1686 Edmund Halley built a map representing for the first time in history the tropical wind circulation, including trades and monsoons using reports from logbooks and several authors have identified their climatic potential (Wheeler and García-Herrera, 2008). However, only in the last decades, several authors and projects have used systematically logbooks from a climate perspective. Catchpole and Faurer (1983) analyzed freezing and ice breaking dates in the Hudson Bay. They have also been very 
useful in the analysis of storms and hurricanes (Mock et al., 2010; Vaquero et al., 2008; Wheeler et al., 2009). Chenoweth (2001) used them to estimate the impact of two major volcanic eruptions in the first half of the $19^{\text {th }}$ century. Later, GarcíaHerrera et al. (2005) showed through the CLIWOC project that wind observations recorded in the logbooks before 1850 where comparable to those of the modern records and, consequently, could be used to extend backwards wind climatologies. Gallego et al. (2005) and Küttel et al. (2006) showed that the wind information over the oceans kept in logbooks can be applied to reconstruct Sea Level Pressure fields in isolation or combined with other climate proxies.

The most recent developments with logbooks include the construction of the so-called wind directional indices; they represent the atmospheric circulation over a certain area by computing the monthly frequency of given wind directions. The phases of the indices are associated to different weather regimes and, depending on the region and season, have an impact on meteorological variables as temperature and precipitation of the downwind zones. Barriopedro et al. (2014) have built the Westerly Index (WI), which is the monthly frequency of westerly winds over the English Channel. This is the longest observational atmospheric index currently available (1685-present). One of the key factors in the drought occurrence over great areas of Europe and the Mediterranean basin is the moisture advection and WI represents well this phenomenon. Further on Vicente-Serrano et al. (2015) have shown that the WI is associated to short-term seasonal droughts as well as to long term summer droughts in that region. In fact, they demonstrate that most of drought variability over Europe during the past two centuries can be explained solely by a combination of the WI and a North Atlantic Oscillation (NAO) index, with the WI mostly associated to droughts in northern and central Europe and the NAO exhibiting the higher signal in Southern Europe and the Mediterranean.

Because of the high density of logbook records in the vicinity of the N Western African coast, Gallego et al. (2015) have been able to build the African Southwesterly Index (ASWI) representing the West African Monsoon since the beginning of the $19^{\text {th }}$ century. As can be seen in Figure 4, during the period 1901-2010 this monsoon is well correlated with precipitation in the Sahel during the monsoon months, peaking in July and August. Consequently, it represents adequately droughts in that key and vulnerable area of the world. The long ASWI record shows that the Sahel precipitation is characterized by significant multidecadal variability, with a succession of dry and wet cycles. According to this index, the period 1800-1840 was characterized by wet periods during the early monsoon months, while the recent Sahel drought, which prevails in that area during the last fifty years, does not have precedents neither in duration not intensity in the last 170 years. 
ASWI-GPCCV6 r(1901-2010) JUN

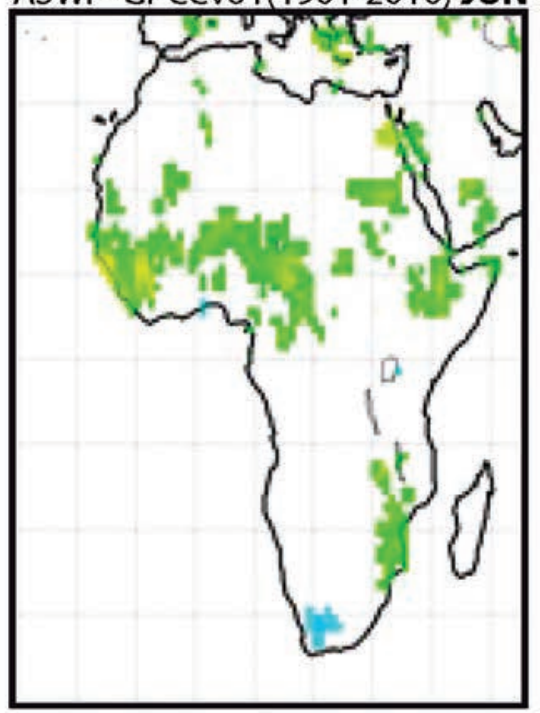

ASWI - GPCCv6r(1901-2010) JUL

ASWI - GPCCv6r(1901-2010) AUG

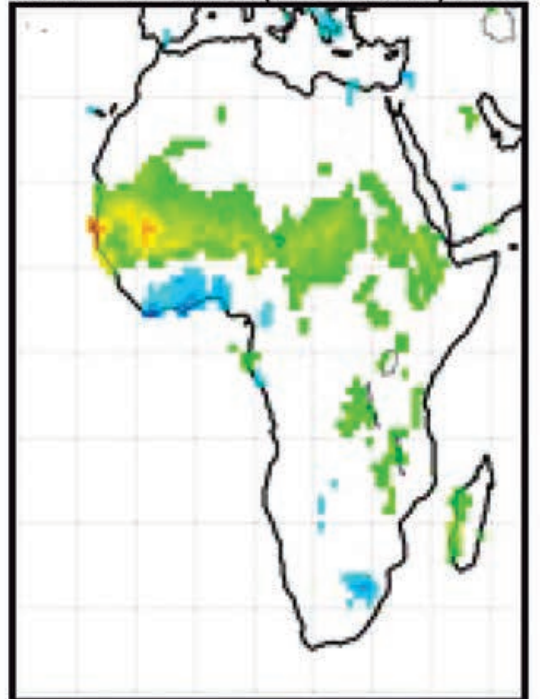

ASWI - GPCCV6 r(1901-2010) SEP
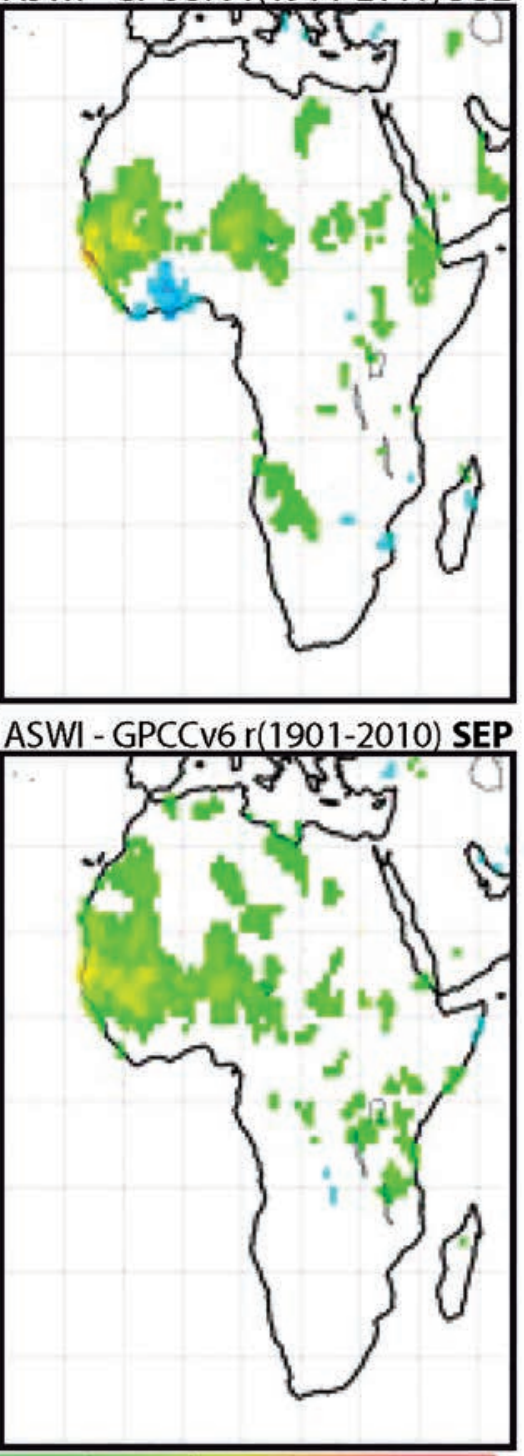

$-1.00$

$-0.80-0.60-0.40-0.20$

0.00

$0.200 .40 \quad 0.60$

0.801 .00

Figure 4. Pearson correlation coefficient between African Southwesterly Index (ASWI) and precipitation taken from the Global Precipitation Climatology Centre (GPCC_v6) (http:// www.deutscherwetterdienst.de/en/FundE/Klima/KLIS/int/GPCC/GPCC.htm) database with $1^{\circ} \times 1^{\circ}$ resolution for the period 1901-2010 (Schneider et al. 2011), for the 4 monsoon months. Only significant correlations $(p<0.05)$ are represented. 


\subsection{Chronicles}

Historical chronicles are documents with the purpose of describing the political and social events that occurred during a determinate time in a location or region. The time span, in some cases, is from the "formation of the world" until the lifetime of the writer. It is frequent that the chronicles start many years prior to the birth of the author, so chronicles are secondary sources and generally discontinuous. The spatial scale goes from a village to an entire empire. The climate is not an important topic in chronicles, so the climatic events documented in chronicles are mainly extreme events that represented a high impact on those societies; observed departures of plant-phenological phases, or other features of seasonality such as snow or ice from those in "ordinary years" (Brázdil et al., 2010).

The lack of interest of the authors in climate events has the advantage that they had no interest in overestimating the associated impact, which can be the case in chapter acts, since the local governments could use them to claim compensations. On the other hand, this explains the difficulty in obtaining long and continuous climatic series from these sources. Moreover, errors in names and in dates due to changes in calendars or transcription are not infrequent. So the work with chronicles must be extremely careful and, when possible, cross checked with other independent sources to verify the accuracy in dates and the reliability of the different authors (Camuffo and Enzi, 1995). However, chronicles may have information from original manuscripts, which in many cases have been lost, and, thus, are the only recipient of this ancient information. Consequently, they are used in climate reconstruction jointly with other documentary sources and natural proxies. However, they are especially useful to describe with detail extreme events with high impact. This is the case of Domínguez-Castro et al. (2014) who studied the Iberian Islamic chronicles from 711 to 1010 to identify extreme drought in Al-Andalus. Three periods of severe droughts were identified, including AD 748754, AD 812-823 and AD 867-879. Domínguez-Castro et al. (2012b) rescued 14 references to drought in Iraq Chronicles for the period ad 845 to ad 990. In summary, chronicles are a discontinuous secondary source, but useful to evaluate individual events.

\section{Final remarks}

Table 1 summarizes the main characteristics of the documentary sources analyzed in this paper, including the relevance for drought analysis. Thus, chapter acts/rogations are probably the most relevant source since they can provide continuous and direct evidence on drought impacts. The interest of logbooks is lower for the measurement of the impact, since they provide indirect information through the circulation indices. However, they can be very helpful to understand the mechanisms and teleconnections associated to droughts. Finally, chronicles have a more limited usefulness due to their secondary nature and because their focus on climate events is very limited. 
Table 1. Main characteristics of documentary sources relevant for drought analysis.

\begin{tabular}{|l|l|l|l|l|l|l|}
\hline \multicolumn{1}{|c|}{ Source } & \multicolumn{1}{|c|}{$\begin{array}{c}\text { Primary/ } \\
\text { Secondary }\end{array}$} & \multicolumn{1}{|c|}{ Continuity } & \multicolumn{1}{c|}{$\begin{array}{c}\text { Time } \\
\text { coverage }\end{array}$} & $\begin{array}{c}\text { Space } \\
\text { coverage }\end{array}$ & \multicolumn{1}{|c|}{ Data type } & $\begin{array}{c}\text { Relevance } \\
\text { for } \\
\text { droughts }\end{array}$ \\
\hline $\begin{array}{l}\text { Chapter } \\
\text { Acts/ } \\
\text { Rogations }\end{array}$ & Primary & $\begin{array}{l}\text { Mostly } \\
\text { continuous } \\
\text { depending of the } \\
\text { preservation of } \\
\text { the documents } \\
\text { century in } \\
\text { Europe and } \\
17^{\text {th }} \text { in the } \\
\text { colonies to } \\
\text { mid } 19^{\text {th }} \text { in } \\
\text { both cases }\end{array}$ & $\begin{array}{l}\text { Continuous } \\
\text { from }\end{array}$ & Local & Extreme events & High \\
\hline Logbooks & Primary & $\begin{array}{l}\text { Continuous } \\
\text { present }\end{array}$ & $\begin{array}{l}\text { Oceanic } \\
\text { routes }\end{array}$ & $\begin{array}{l}\text { Meteorological } \\
\text { variables } \\
\text { instrumental or } \\
\text { observational }\end{array}$ & Medium \\
\hline Chronicles & Secondary & $\begin{array}{l}\text { Discontinuous. } \\
\text { Some exception } \\
\text { during the life } \\
\text { time of the } \\
\text { authors. }\end{array}$ & $\begin{array}{l}2000 \text { B.C- } \\
\text { present }\end{array}$ & $\begin{array}{l}\text { Local to } \\
\text { national }\end{array}$ & Extreme events & $\begin{array}{l}\text { High for } \\
\text { specific } \\
\text { events }\end{array}$ \\
\hline
\end{tabular}

It must be emphasized that the examples shown in this paper are just a sample of the increasing development in the last decades, mostly in Europe, to analyze droughts during the historical period. The potential of documentary records to generate climatic information is far from being exploited due to a number of factors such as reduction in research funding, difficulties in the access to documents, since most archives are not digitized yet, or the limited interest of historians in environmental and climatic history. However the multidisciplinary cooperation to recover and analyze these documents should be encouraged since the feedback between historians and climatologists improves the understanding of historical processes (Parker, 2013) and, reversely, a finer picture of climate variability.

\section{Acknowledgements}

Fernando Domínguez-Castro was supported by the Ecuadorian Government (Secretaría de Educación Superior, Ciencia, Tecnología e Innovación) through a PROMETEO project.

\section{References}

Álvarez Vázquez, J.A. 1986. Drought and Rainy Periods in the Province of Zamora in the 17th, 18th, and 19th Centuries. In F. López-Vera (ed.), Quaternary Climate in Western Mediterranean, Universidad Autónoma de Madrid, Madrid, pp. 221-233.

Barriendos, M. 1997. Climatic variations in the Iberian peninsula during the late Maunder minimum (AD 1675-1715): an analysis of data from rogation ceremonies. The Holocene 7, 105-111.

Barriopedro, D., Gallego, D., Álvarez-Castro, M.C., García-Herrera, R., Wheeler, D., Peña-Ortiz, C., Barbosa, S.M. 2014. Witnessing North Atlantic westerlies variability from ship's logbooks (1685-2008). Climate Dynamics 43 (3), 939-955. Doi: 10.1007/s00382-013-1957-8. 
Belmonte, M.C., Cuesta, M., Pozas, L., García, M.I. 1987. Las actas capitulares como fuente para la historia urbana. En la España Medieval 10, 39-68.

Brázdil, R., Dobrovolný, P., Luterbacher, J., Moberg, A., Pfister, C., Wheeler, D., Zorita, E. 2010. European climate of the past 500 years: new challenges for historical climatology. Climatic Change 101, 7-40.

Camuffo, D., Enzi, S. 1995. Reconstructing the climate of northern Italy from archive sources. In R. Bradley, P.D. Jones (eds.), Climate since A.D. 1500. Routledge, London, pp. 143-154.

Catchpole, A.J.W., Faurer M.A. 1983. Summer sea ice severity in Hudson Strait, 1751-1870. Climatic Change 5, 115-139.

Chenoweth, M. 2001. Two major volcanic cooling episodes derived from global marine air temperature data, AD 1807-1827. Geophysical Research Letters 28, 2963-2966.

Cuadrat, J.M. 2012. Reconstrucción de los episodios de sequía en el nordeste España a partir de las ceremonias de rogativas. Nimbus: Revista de climatología, meteorología y paisaje 29-30, 177-187.

de Dios Navas, J. 1926. Guápulo y su Santuario. Imprenta del Clero, Quito, 436 pp.

Domínguez-Castro, F., García-Herrera, R., Ribera, P., Barriendos, M. 2010. A shift in the spatial pattern of Iberian droughts during the 17th century. Climate of the Past 6, 553-563.

Domínguez-Castro, F., de Miguel, J.C., Vaquero, J.M., Gallego, M.C., García-Herrera, R. 2014. Climatic potential of Islamic chronicles in Iberia: Extreme droughts (AD 711-1010). The Holocene 24 (3), 370-374.

Domínguez-Castro, F., Ribera, P., García-Herrera, R. Vaquero, J.M., Barriendos, M., Moreno, J.M. 2012a. Assessing extreme droughts in Spain during 1750-1850 from rogation ceremonies. Climate of the Past 8 (2), 705-722.

Domínguez-Castro, F., Vaquero, J.M., Marín, M., Gallego, M.C., García-Herrera, R. 2012b. How useful could Arabic documentary sources be for reconstructing past climate? Weather 67 (3), 76-82.

Domínguez-Castro, F., Santisteban, J.I., Barriendos, M., Mediavilla, R. 2008. Reconstruction of drought episodes for central Spain from rogation ceremonies recorded at Toledo Cathedral from 1506 to 1900: A methodological approach. Global and Planetary Change 63, 230-242.

Domínguez-Castro, F., Santisteban, J.I., Mediavilla, R., Dean, W.E., López-Pamo, E., Gil-García, M.J., Ruiz-Zapata, M.B., 2006. Environmental and geochemical record of human-induced changes in $\mathrm{C}$ storage during the last millennium in a temperate wetland (Las Tablas de Daimiel National Park, central Spain). Tellus B 58 (8), 573-585.

Domínguez-Castro, F., Villacís, M., Vaquero, J.M., García-Herrera, R., Monero, G. 2015. Reconstructing climate of Ecuador: Potential of documentary sources. In XIX INQUA Congress, Nagoya.

Esper, J., Großjean, J., Camarero, J.J, García-Cervigón, A.I., Olano, J.M., González-Rouco, J.F., Domínguez-Castro, F., Büntgen, U. 2015. Atlantic and Mediterranean synoptic drivers of central Spanish juniper growth. Theoretical and Applied Climatology 121 (3), 571-579. Doi: 10.1007/s00704-014-1254-4.

Fernández-Fernández, M.I., Gallego, M.C., Domínguez-Castro, F., Trigo, R.M., Vaquero, J.M. 2014. The climate in Zafra from 1750 to 1840: Precipitation. Climatic Change 129, 267-280.

Gallego, D., García-Herrera, R., Ribera, P., Jones, P.D. 2005. Seasonal mean pressure reconstruction for the North Atlantic (1750-1850) based on early marine data. Climate of the Past 1, 19-33.

Gallego, D., Ordóñez, P., Ribera, P., Peña-Ortiz, C., García-Herrera, R. 2015. An instrumental index of the West African Monsoon back to the nineteenth century. Quarterly Journal of the Royal Meteorological Society 141(693), 3166-3176. Doi: 10.1002/qj.2601. 
García-Herrera, R., Díaz, H.F., García, R.R., Prieto, M.R., Barriopedro, D., Moyano, R., Hernández, E. 2008. A chronology of El Niño events from primary documentary sources in Northern Peru. Journal of Climate 21 (9), 1948-1962. Doi: 10.1175/2007JCLI1830.1.

García-Herrera, R., Können, G., Wheeler, D., Prieto, M.R., Jones, P., Koek, F. 2005. A climatological database for the world's oceans 1750-1854. Climatic Change 73, 1-12.

García-Herrera, R., Paredes, D., Trigo, R.M., Trigo, I.F., Hernández, E., Barriopedro, D., Mendes, M.A. 2007. The outstanding 2004-2005 drought in the Iberian Peninsula: Impacts and atmospheric circulation associated. Journal of Hydrometeorology 8 (3), 483-498. Doi: 10.1175/JHM578.1.

Garza Merodio, G.G. 2007. Climatología Histórica: las ciudades mexicanas ante la sequía (siglos XVII al XIX). Investigaciones Geográficas, Boletín del Instituto de Geografía UNAM 63, 77-92.

Garza Merodio, G.G. 2014. Little Ice Age characteristics in Central Mexico through documentary sources. Investigaciones Geográficas. Boletín del Instituto de Geografía 85, 82-94.

Hodell, D.A., Brenner, M., Curtis, J.H. 2005. Terminal Classic drought in the northern Maya lowlands inferred from multiple sediment cores in Lake Chichancanab (Mexico). Quaternary Science Reviews 24 (12-13), 1413-1427.

Ionita, M., Lohmann, G., Rimbu, N., Chelcea, S., Dima, M. 2011. Interannual to decadal summer drought variability over Europe and its relationship to global sea surface temperature. Climate Dynamics 38 (1), 363-377.

Küttel, M., Xoplaki, E., Gallego, D., Luterbacher, J., García-Herrera, R., Allan, R., Barriendos, M., Jones, P.D., Wheeler, D., Wanner, H. 2009. The importance of ship log data: reconstructing North Atlantic, European and Mediterranean sea level pressure fields back to 1750. Climate Dynamics 34, 1115-1128.

Martín-Puertas, C., Valero-Garcés, B.L., Mata, M.P., González-Sampériz, P., Bao, R., Moreno, A., Stefanova, V. 2008. Arid and humid phases in southern Spain during the last 4000 years: the Zoñar Lake record, Córdoba. The Holocene 18 (6), 907-921.

Martín-Vide, J., Barriendos, M. 1995. The use of rogation ceremony records in climatic reconstruction: a case study from Catalonia (Spain). Climatic Change 30, 201-221.

Mock, C.J., Chenoweth, M., Altamirano, I., Rodgers, M.D., García-Herrera, R. 2010. The great Louisiana Hurricane of August 1812. Bulletin of the American Meteorological Society 91, 1653-1663.

Nash, D., Adamson, G. 2014. Recent advances in the historical climatology of the tropics and subtropics. Bulletin of the American Meteorological Society 95, 131-146.

Nelson, D.B., Abbott, M.B., Steinman, B., Polissar, P.J., Stansell, N.D., Ortiz, J.D., Rosenmeier, M.F., Finney, B.P., Riedel, J. 2011. Drought variability in the Pacific Northwest from a 6000yr lake sediments record. PNAS 108 (10), 3870-3875.

Obasi, G.O.P. 1994. WMO's Role in the international decade for natural disaster reduction. Bulletin of the American Meteorological Society 75, 1655-1661.

Paredes, D., Trigo, R.M., García-Herrera, R., Trigo, I., Valente, M.A. 2006. Understanding precipitation changes in Iberia in early spring: weather typing and storm-tracking approaches. Journal of Hydrometeorology 7 (1), 101-113.

Parker, G. 2013. Global Crisis: War, Climate Change and Catastrophe in the Seventeenth Century. Yale University Press, New Haven, 672 pp.

Piervitali, E., Colacino, M. 2001. Evidence of drought in Western Sicily during the period 15651915 from liturgical offices. Climatic Change 49, 225-238.

Politis, G. 1983. Climatic variations during historical times in Eastern Buenos Aires Pampas, Argentina. Quaternary of South America and Antartic Peninsula 2, 133-161. 
Prieto, M.R., García-Herrera, R. 2009. Documentary sources from South America: potential for climate reconstruction. Palaeogeography Palaeoclimatology Palaeoecology 281, 196-209.

Rodrigo, F.S., Barriendos, M. 2008. Reconstruction of seasonal and annual rainfall variability in the Iberian Peninsula (16th-20th Centuries) from documentary data. Global and Planetary Change 63, 243-257.

Sáez de Ocáriz, M. 1990. Climatología y régimen de lluvias en La Rioja Alta, siglos XVI al XIX. Zubia 8, 129-178.

Schneider, U., Becker, A., Finger, P., Meyer-Christoffer, A., Rudolf, B., Ziese, M. 2011. GPCC Full Data Reanalysis Version 6.0 at $1.0^{\circ}$ : Monthly Land-Surface Precipitation from RainGauges built on GTS-based and Historic Data. Doi: 10.5676/DWD_GPCC/FD_M_V7_100.

Sousa, P.M., Trigo, R.M., Aizpurua, P., Nieto, R., Gimeno, L., García-Herrera, R. 2011. Trends and extremes of drought indices throughout the $20^{\text {th }}$ century in the Mediterranean. Natural Hazards and Earth System Sciences 11, 33-51.

Stahle, D.W., Fye, F.K., Cook, E.R., Griffin, R.D. 2007. Tree-ring reconstructed megadroughts over North America since A.D. 1300. Climate Change 83, 133-149.

Tejedor, E., de Luis, M., Cuadrat, J.M., Esper, J., Saz, M.A. 2015. Tree-ring-based drought reconstruction in the Iberian Range (East of Spain) since 1694. International Journal of Biometeorology. Doi: 10.1007/s00484-015-1033-7.

Terneus, A., Gioda, A. 2006. In search of colonial El Niño events and a brief history of meteorology in Ecuador. Advances in Geosciences 6, 181-187.

Vaquero, J.M., García-Herrera, R., Wheeler, D., Chenoweth, M., Mock, C. 2008. A historical analogue of 2005 hurricane Vince. Bulletin of the American Meteorological Society 89, 191201. Doi: 10.1175/BAMS-89-2-191.

Verschuren, D., Kathleen, L.R., Cumming, B.F. 2000. Rainfall and drought in equatorial east Africa during the past 1,100 years. Nature 403, 410-414.

Vicente Serrano, S.M., Cuadrat, J.M. 2007. North Atlantic oscillation control of drought in northeast Spain: evaluation since 1600 A.D. Climatic Change 85, 357-379.

Vicente-Serrano, S.M., García-Herrera, R., Barriopedro, D., Azorín-Molina, C., López-Moreno, J.I., Gimeno, L., Nieto, R. 2015. The Westerly Index as complementary indicator of the North Atlantic Oscillation in explaining drought variability across Europe. Climate Dynamics. Doi: 10.1007/s00382-015-2875-8.

Vicente-Serrano, S.M., López-Moreno, J.I. 2008. Nonstationary influence of the North Atlantic Oscillation on European precipitation. Journal of Geophysical Research 113, D20120. Doi: 10.1029/2008JD010382.

Wheeler, D., García-Herrera, R. 2008. Ship's logbooks in climatological research: reflections and prospects. Annals of the New York Academy of Science 1146, 1-15.

Wheeler, D., García-Herrera, R., Vaquero, J.M., Chenoweth, M., Mock, C. 2009. Reconstructing the trajectory of the August 1680 Hurricane from contemporary records. Bulletin of the American Meteorological Society 90 (7), 971-978.

Wilhite, D.A., Glantz, M.H. 1985. Understanding: the Drought Phenomenon: The Role of Definitions. Water International 10, 111-120.

Zamora, R. 2002. El final de la Pequeña Edad de Hielo. Publicaciones de la Universidad de Alicante, Alicante, $194 \mathrm{pp}$. 